\title{
Electrochemical Extraction of Rare Earth Metals in Molten Fluorides: Conversion of Rare Earth Oxides into Rare Earth Fluorides Using Fluoride Additives
}

\author{
Aida Abbasalizadeh ${ }^{1}\left(\mathbb{D} \cdot\right.$ Annelies Malfliet $^{2} \cdot$ Seshadri Seetharaman $^{3} \cdot$ \\ Jilt Sietsma $^{1} \cdot$ Yongxiang Yang ${ }^{1}$
}

Published online: 6 April 2017

(c) The Author(s) 2017. This article is an open access publication

\begin{abstract}
In the present research on rare earth extraction from rare earth oxides (REOs), conversion of rare earth oxides into rare earth fluorides with fluoride fluxes is investigated in order to overcome the problem of low solubility of the rare earth oxides in molten fluoride salts as well as the formation of oxyfluorides in the fluorination process. Based on thermodynamic calculations, a series of experiments were performed for converting the rare earth oxides into rare earth fluorides using $\mathrm{AlF}_{3}, \mathrm{ZnF}_{2}, \mathrm{FeF}_{3}$, and $\mathrm{Na}_{3} \mathrm{AlF}_{6}$ as fluorinating agents in a $\mathrm{LiF}-\mathrm{Nd}_{2} \mathrm{O}_{3}$ system. The formation of neodymium fluoride as a result of the reactions between these fluxes and neodymium oxide is confirmed. The rare earth fluoride thus formed can subsequently be processed through the electrolysis route in the same reactor, and rare earth metal can be produced as the cathodic deposit. In this concept, the REO dissolution in molten fluorides would become unnecessary due to the complete conversion of the oxide into the fluoride, $\mathrm{REF}_{3}$. The results of XRD and EPMA analysis of the reacted samples indicate that $\mathrm{AlF}_{3}, \mathrm{ZnF}_{2}$, and $\mathrm{FeF}_{3}$ can act as strong fluorinating agents for the neodymium oxide giving rise to a complete conversion of neodymium oxide into neodymium fluoride.
\end{abstract}

The contributing editor for this article was U. Pal.

Aida Abbasalizadeh

a.abbasalizadeh@tudelft.nl

1 Department of Materials Science and Engineering, Delft University of Technology, Mekelweg 2, 2628CD Delft, The Netherlands

2 Department of Materials Engineering, KU Leuven, Kasteelpark Arenberg 44, 3000 Leuven, Belgium

3 Royal Institute of Technology (KTH), Stockholm, Sweden
Keywords Rare earth oxides - Rare earth fluorides . Recycling · Fluorination

\section{Introduction}

Rare earth oxides are among the most stable oxides of the elements in the periodic table. Oxygen removal from rare earth metals is therefore very difficult due to the strong affinity of these metals to oxygen.

Chen et al. [1] have developed a direct electrochemical process for the reduction of solid metal oxides into their metals in molten salts, the FFC process. This method has been extensively adopted in metal extraction for a number of elements including rare earth metals $(\mathrm{RE}=\mathrm{Gd}, \mathrm{Tb}, \mathrm{Dy}$, $\mathrm{Er}$, and Ce) [2-4]. The direct electrochemical reduction of oxide into metal is influenced by a number of parameters such as duration of electrolysis, temperature, applied voltage, open porosity of the oxide pellet, and mode of electrolysis [5]. The efficiency of the oxygen removal by direct electrochemical reduction of oxides is mainly determined by the geometry of the samples, the surface area of the solid sample in contact with the molten salt, and the initial oxygen concentrations. The FFC process has not yet been commercialized, and one of the main challenges is the residual oxygen concentration in the reduced metal.

Electrowinning (molten salt electrolysis) is the dominating industrial method for rare earth metal extraction from their oxides in the salt extraction process [6-8]. It is generally considered that in an electrowinning process, it is the dissolved oxide in the electrolyte that is subjected to electrolysis [9]. Hence in fluoride systems, solubility of the oxide in fluoride electrolytes is an important parameter. Generally, molten fluorides have a low oxide solubility, except for cryolite, which has a high solubility for alumina 
(about $10 \mathrm{wt} \%$ ); the solubility of neodymium oxide in molten alkali fluorides was reported to be $2-4 \mathrm{wt} \%$ $[10,11]$. The concentration of dissolved oxide cannot be increased by adding excess oxide into the melt at a constant temperature and fixed salt composition. Nevertheless, addition of an excess quantity of oxide into the melt can increase the kinetics of the reactions. Besides the low solubility of rare earth oxides in molten fluorides, another problem for metals extraction that needs to be addressed is that these oxides can form rare earth oxyfluorides in the $\mathrm{LiF}-\mathrm{NdF}_{3}$ molten salt. It has been reported that neodymium oxyfluorides cannot be reduced to neodymium metal [12]. It has been confirmed that neodymium oxyfluoride participates in the anodic reaction to generate oxygen [13]. However, the role of neodymium oxyfluoride in the anodic and cathodic reactions is not very clear and needs to be clarified further in detail [12-16].

In the present work, a new approach is proposed for solving the problem of low oxide solubility and oxyfluoride formation of rare earth oxides (REOs) in molten fluorides. Addition of fluorinating agents such as $\mathrm{AlF}_{3}, \mathrm{ZnF}_{2}$, and $\mathrm{FeF}_{3}$ to the $\mathrm{LiF}-\mathrm{Nd}_{2} \mathrm{O}_{3}$ system changes the thermodynamic equilibrium and thus allows conversion of REOs into rare earth fluorides. Use of cryolite $\left(\mathrm{Na}_{3} \mathrm{AlF}_{6}\right)$ as a fluorinating agent, and as a substitute for $\mathrm{AlF}_{3}$, was also investigated, due to its availability and cost advantages. By treatment with fluorinating agents, the rare earth oxide is converted into rare earth fluoride. The rare earth fluoride thus formed can subsequently be processed through the electrolysis route in the same reactor to extract rare earth metal as the cathodic deposit. In this concept, the REO dissolution in molten fluorides would become redundant due to the complete conversion of the oxide into the fluoride, $\mathrm{REF}_{3}$.

\section{Thermodynamics of the Process}

The standard Gibbs free energies $\left(\Delta G^{\circ}\right.$ ) for the formation of the reacted fluorides and oxides at $1223 \mathrm{~K}\left(950{ }^{\circ} \mathrm{C}\right)$, calculated using FactSage, are given in Table 1. A decrease in the stability of fluorides formed was observed in the following order: $\mathrm{CaF}_{2}>\mathrm{LiF}>\mathrm{NaF}>\mathrm{KF}$. The decomposition voltages of rare earth fluorides and the alkali fluorides are also compared in Table 1. It can be seen that only $\mathrm{CaF}_{2}$ and $\mathrm{LiF}$ are more stable than $\mathrm{NdF}_{3}$ and $\mathrm{DyF}_{3}$. Thus, for the electrochemical decomposition of REOs into fluorides, the most suitable solvents among fluorides need to be based on $\mathrm{CaF}_{2}$ and $\mathrm{LiF}$.

In the present work, $\mathrm{AlF}_{3}, \mathrm{ZnF}_{2}, \mathrm{FeF}_{3}$, and $\mathrm{Na}_{3} \mathrm{AlF}_{6}$ are tested as candidates for the fluorination of REOs prior to electrolysis in molten fluoride bath. From the calculated standard Gibbs energies of the reactions (1)-(4) at $1223 \mathrm{~K}$ $\left(950{ }^{\circ} \mathrm{C}\right)$

$$
\begin{gathered}
\mathrm{Nd}_{2} \mathrm{O}_{3}+2 \mathrm{AlF}_{3}(\text { salt }) \rightleftarrows 2 \mathrm{NdF}_{3}+\mathrm{Al}_{2} \mathrm{O}_{3} \\
\Delta G^{\circ}=-177 \mathrm{~kJ} / \mathrm{mol} \\
\mathrm{Nd}_{2} \mathrm{O}_{3}+3 \mathrm{ZnF}_{2}(\text { salt }) \rightleftarrows 2 \mathrm{NdF}_{3}+3 \mathrm{ZnO} \\
\Delta G^{\circ}=-274 \mathrm{~kJ} / \mathrm{mol} \\
\mathrm{Nd}_{2} \mathrm{O}_{3}+2 \mathrm{FeF}_{3}(\text { salt }) \rightleftarrows 2 \mathrm{NdF}_{3}+\mathrm{Fe}_{2} \mathrm{O}_{3} \\
\Delta G^{\circ}=-222 \mathrm{~kJ} / \mathrm{mol} \\
\mathrm{Nd}_{2} \mathrm{O}_{3}+\mathrm{Na}_{3} \mathrm{AlF}_{6}(\text { salt }) \rightleftarrows \mathrm{NdF}_{3}+\mathrm{Al}_{2} \mathrm{O}_{3}+3 \mathrm{NaF} \\
\Delta G^{\circ}=-23.4 \mathrm{~kJ} / \mathrm{mol}
\end{gathered}
$$

it is evident that these metal fluorides can react with REOs to form rare earth fluorides, and the formed $\mathrm{NdF}_{3}$ can further be reduced at the cathode. The metal oxides $\mathrm{Al}_{2} \mathrm{O}_{3}$, $\mathrm{ZnO}$, and $\mathrm{Fe}_{2} \mathrm{O}_{3}$ are formed in the system during the formation of $\mathrm{NdF}_{3}$. It should be noted that in argon atmosphere and at low oxygen pressure, in reaction (3), it is expected that, instead of $\mathrm{Fe}_{2} \mathrm{O}_{3}, \mathrm{FeO}$ could be formed which means that $\mathrm{Fe}_{2} \mathrm{O}_{3}$ will be in the form of $\mathrm{FeO}$ and $\mathrm{O}_{2}$ under experimental conditions.

$\mathrm{NdF}_{3}$, formed as a result of the reaction between $\mathrm{Nd}_{2} \mathrm{O}_{3}$ and $\mathrm{MF}_{x}(\mathrm{M}=\mathrm{Al}, \mathrm{Zn}, \mathrm{Fe})$ or $\mathrm{Na}_{3} \mathrm{AlF}_{6}$, will be subjected to electrolysis. In this process, in theory, the main cathodic reaction would be

$\mathrm{Nd}^{3+}+3 \mathrm{e}^{-} \rightleftarrows \mathrm{Nd}$

According to reactions (1)-(4), during the $\mathrm{Nd}_{2} \mathrm{O}_{3}$ conversion into $\mathrm{NdF}_{3}$ by $\mathrm{AlF}_{3}, \mathrm{ZnF}_{2}, \mathrm{FeF}_{3}$, or $\mathrm{Na}_{3} \mathrm{AlF}_{6}$, the corresponding oxides $\mathrm{Al}_{2} \mathrm{O}_{3}, \mathrm{ZnO}, \mathrm{FeO}$, and $\mathrm{Al}_{2} \mathrm{O}_{3}$, respectively, are formed in the salt. Since the stability of these oxides is lower than that of $\mathrm{NdF}_{3}$, parts of $\mathrm{Al}_{2} \mathrm{O}_{3}$, $\mathrm{ZnO}$, and $\mathrm{FeO}$ might dissolve in the fluoride melt and get subjected to the electrolysis process. The solubility of alumina in the molten fluorides is $6 \mathrm{~mol} \%$ [17]. Based on the density of the LiF containing different concentrations of $\mathrm{NdF}_{3}$ [18], an estimation shows that the density of LiF$5 \mathrm{~mol} \% \mathrm{NdF}_{3}$ is $4 \mathrm{~g} / \mathrm{cm}^{3}$ (aluminum oxide density is $3.95 \mathrm{~g} / \mathrm{cm}^{3}$ ). This means that the critical composition in which the aluminum oxide will start floating is LiF$5 \mathrm{~mol} \% \mathrm{NdF}_{3}$. The floating oxide can be then removed from the top of the liquid. The density of the $\mathrm{LiF}-\mathrm{NdF}_{3}$ system can go up to $5 \mathrm{~g} / \mathrm{cm}^{3}$ when $\mathrm{NdF}_{3}$ reaches $50 \mathrm{~mol} \%$. Yet $\mathrm{ZnO}$ and $\mathrm{FeO}$ have higher density $\left(5.6\right.$ and $5.74 \mathrm{~g} / \mathrm{cm}^{3}$, respectively), so the oxide formed will sink in the liquid and should be removed. If the newly formed oxide could be removed before electrolysis, the co-deposition could be minimized. For the separation of newly formed oxide solids from the molten salt (for electrolysis), a two-chamber inter-connected furnace system can be designed: $\mathrm{NdF}_{3}$ conversion chamber-1 and $\mathrm{NdF}_{3}$ electrolysis chamber- 2 . By arranging the connection channel in the middle or the 
Table 1 Standard Gibbs energies and decomposition voltages of different fluoride salts and REOs and $\mathrm{REF}_{3}(\mathrm{RE}=\mathrm{Nd}, \mathrm{Dy})$

\begin{tabular}{llll}
\hline Reaction & $\begin{array}{l}\Delta G^{\circ}(\mathrm{kJ} / \mathrm{mol}) \text { at } \\
1223 \mathrm{~K}\left(950^{\circ} \mathrm{C}\right)\end{array}$ & $\begin{array}{l}\text { Decomposition potential } \\
(\mathrm{V}) \text { at } 1223 \mathrm{~K}\left(950^{\circ} \mathrm{C}\right)\end{array}$ & $\begin{array}{l}\Delta G^{\circ}(\mathrm{kJ} / \mathrm{mol}) \text { at } \\
298 \mathrm{~K}\left(25^{\circ} \mathrm{C}\right)\end{array}$ \\
\hline $\mathrm{CaF}_{2} \rightleftarrows \mathrm{Ca}+\mathrm{F}_{2}$ & 1020 & -5.3 & 1173 \\
$\mathrm{LiF} \rightleftarrows \mathrm{Li}+1 / 2 \mathrm{~F}_{2}$ & 497 & -5.2 & 584 \\
$\mathrm{NaF} \rightleftarrows \mathrm{Na}+1 / 2 \mathrm{~F}_{2}$ & 442 & -4.6 & 544 \\
$\mathrm{KF} \rightleftarrows \mathrm{K}+1 / 2 \mathrm{~F}_{2}$ & 433 & -4.5 & 538 \\
$\mathrm{NdF}_{3}(\mathrm{~s}) \rightleftarrows \mathrm{Nd}(\mathrm{s})+3 / 2 \mathrm{~F}_{2}(\mathrm{~g})$ & 1370 & -4.7 & 1590 \\
$\mathrm{DyF}_{3}(\mathrm{~s}) \rightleftarrows \mathrm{Dy}(\mathrm{s})+3 / 2 \mathrm{~F}_{2}(\mathrm{~g})$ & 1392 & -4.8 & 1614 \\
$\mathrm{Nd}_{2} \mathrm{O}_{3}(\mathrm{~s}) \rightleftarrows 2 \mathrm{Nd}(\mathrm{s})+3 / 2 \mathrm{O}_{2}(\mathrm{~g})$ & 1464 & -2.5 & 1718 \\
$\mathrm{Dy}_{2} \mathrm{O}_{3}(\mathrm{~s}) \rightleftarrows 2 \mathrm{Dy}(\mathrm{s})+3 / 2 \mathrm{O}_{2}(\mathrm{~g})$ & 1508 & -2.6 & 1771 \\
\hline
\end{tabular}

bottom level (depending on the density of the newly formed oxide), the new oxide particles can be removed from the top or bottom, before entering the electrolysis chamber.

The decomposition voltages of these oxides as well as their corresponding fluorides are compared with neodymium fluorides as shown in Fig. 1. These data are calculated for pure substances at their standard states at the specified temperatures. In the real system, the activity values of the fluorides and the oxides will deviate from unity (standard state) due to the dissolution in the salt bath. Yet these data are crucial for the comparison of the different fluorides.

Based on the stability line of the different compounds in Fig. 1, addition of $\mathrm{AlF}_{3}, \mathrm{ZnF}_{2}, \mathrm{FeF}_{3}$, and $\mathrm{Na}_{3} \mathrm{AlF}_{6}$ to the $\mathrm{LiF}-\mathrm{Nd}_{2} \mathrm{O}_{3}$ system and subsequent electrolysis (with a cell voltage of $\sim 4.8 \mathrm{~V}$ at $T=950{ }^{\circ} \mathrm{C}$, without considering the overpotential) would enable the extraction of neodymium from neodymium fluoride. It is also expected that $\mathrm{Al}, \mathrm{Zn}$ and $\mathrm{Fe}$ will be co-deposited on the cathode, forming $\mathrm{Nd}-$ $\mathrm{Al}, \mathrm{Nd}-\mathrm{Zn}$ and $\mathrm{Nd}-\mathrm{Fe}$ alloys if there are remaining $\mathrm{AlF}_{3}$,

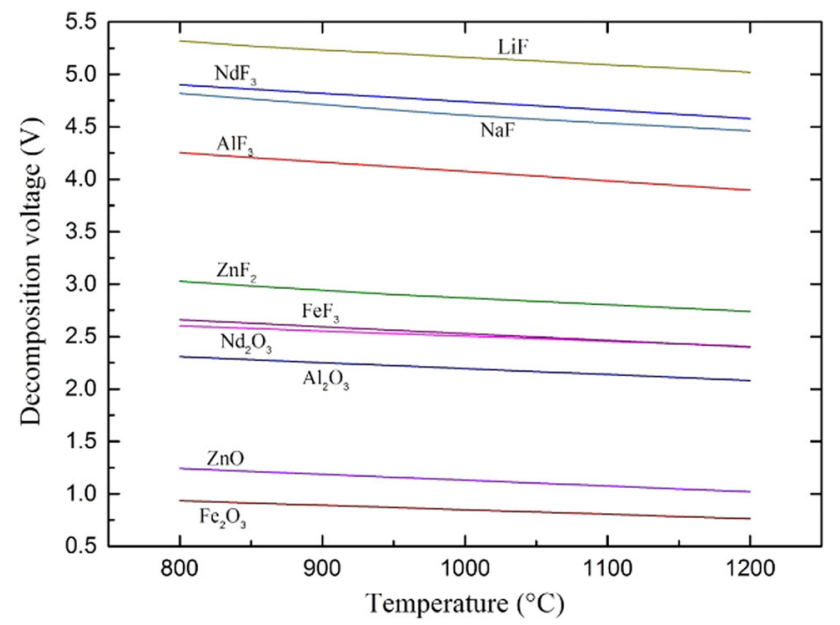

Fig. 1 Decomposition voltages of metal oxides and fluorides calculated by FactSage
$\mathrm{ZnF}_{2}$ or $\mathrm{FeF}_{3}$ in the salt or the $\mathrm{Al}_{2} \mathrm{O}_{3}, \mathrm{ZnO}$ or $\mathrm{Fe}_{2} \mathrm{O}_{3}$ that are formed are dissolved in the salt and participate in the electrochemical reactions. In the case of using cryolite, $\mathrm{Na}$ deposition on cathode is also expected. Hence, along with the reaction (4), one of the following reactions can take place at the cathode:

$\mathrm{Al}^{3+}+3 \mathrm{e}^{-} \rightleftarrows \mathrm{Al}$

$\mathrm{Zn}^{2+}+2 \mathrm{e}^{-} \rightleftarrows \mathrm{Zn}$

$\mathrm{Fe}^{3+}+3 \mathrm{e}^{-} \rightleftarrows \mathrm{Fe}$

$\mathrm{Na}^{+}+\mathrm{e}^{-} \rightleftarrows \mathrm{Na}$

The following anodic reactions will take place if a graphite anode is used:

$\mathrm{O}^{2-}($ salt $)+\mathrm{C}($ anode $) \rightleftarrows \mathrm{CO}(\mathrm{g})+2 \mathrm{e}^{-}$

$2 \mathrm{O}^{2-}($ salt $)+\mathrm{C}($ anode $) \rightleftarrows \mathrm{CO}_{2}(\mathrm{~g})+4 \mathrm{e}^{-}$

$2 \mathrm{~F}^{-}$(salt) $\rightleftarrows \mathrm{F}_{2}(\mathrm{~g})+2 \mathrm{e}^{-}$

A schematic diagram of the salt extraction process including the fluorinating step and the electrochemical RE extraction step is shown in Fig. 2.

\section{Experiments}

Lithium fluoride (98.5\%-Alfa Aesar) was mixed with neodymium oxide (Rhodia) in a glove box. A fluorinating agent of aluminum fluoride (99+\%-Alfa Aesar), zinc fluoride (99\%-Alfa Aesar), iron fluoride (97\%-Alfa Aesar), or cryolite (97\%-Sigma Aldrich) was added to the mixture separately, and the mixture was charged into a graphite crucible. The ratio of neodymium fluoride to fluorinating agent were prepared based on the stoichiometry of Eqs. 14; $\mathrm{Nd}_{2} \mathrm{O}_{3}: 2 \mathrm{AlF}_{3}, \mathrm{Nd}_{2} \mathrm{O}_{3}: 3 \mathrm{ZnF}_{2}, \mathrm{Nd}_{2} \mathrm{O}_{3}: 2 \mathrm{AlF}_{3}$ and $\mathrm{Nd}_{2}$ $\mathrm{O}_{3}: \mathrm{Na}_{3} \mathrm{AlF}_{6}$. No excessive fluorinating agents were added more than the theoretical requirement. LiF concentration was determined assuming that after reaching the complete 


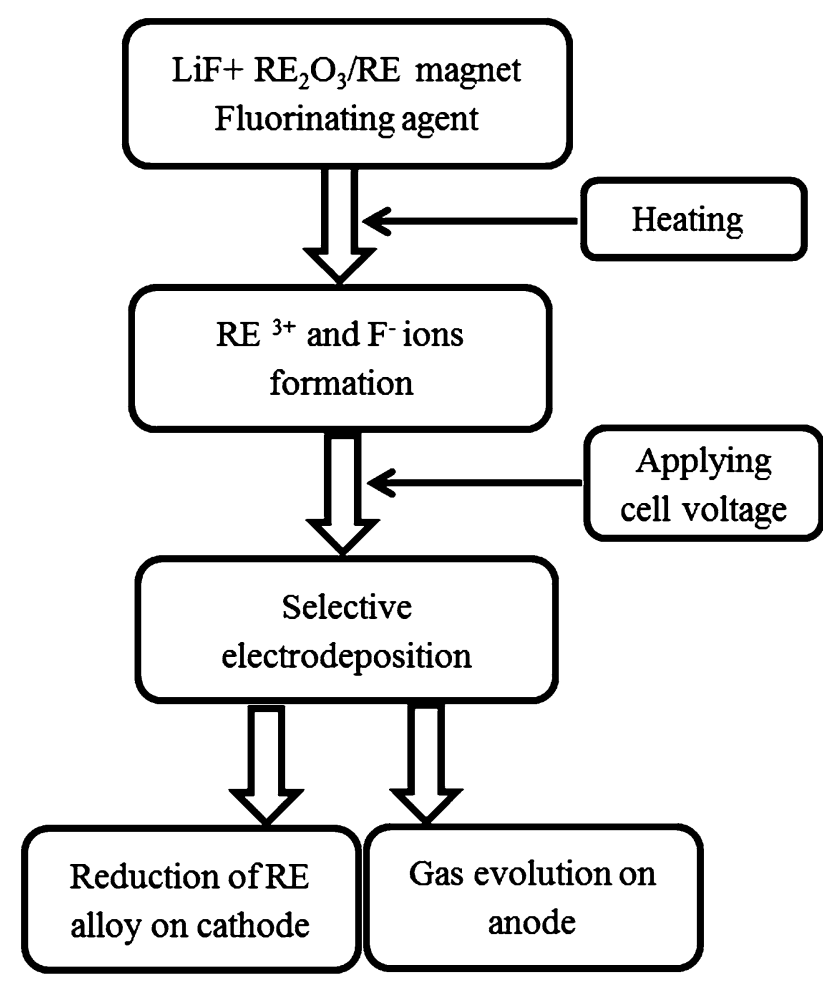

Fig. 2 Schematic diagram of the salt extraction process for extraction of RE from REOs

conversion of $\mathrm{Nd}_{2} \mathrm{O}_{3}$ to $\mathrm{NdF}_{3}$, the eutectic composition of LiF-23 mol\% $\mathrm{NdF}_{3}[19]$ is formed in the system. The total amount of the mixture for all the systems was about $30 \mathrm{~g}$. The mixtures were heated at $1223 \mathrm{~K}\left(950^{\circ} \mathrm{C}\right)$ for $3 \mathrm{~h}$ in a purified argon atmosphere. The $\mathrm{Ar}$ gas was purified by passing through $\mathrm{KOH}$ flakes in order to remove sulfur and also through silica gel and $\mathrm{P}_{2} \mathrm{O}_{5}$ to remove moisture. The gas was passed through a tube furnace containing $\mathrm{Ti}$ sponges which was held at $1123 \mathrm{~K}\left(850{ }^{\circ} \mathrm{C}\right)$ in order to remove the traces of $\mathrm{O}_{2}$. The samples were quenched in liquid nitrogen after the experiment.

The samples were analyzed by X-ray diffractometry (XRD) as well as electron probe microanalysis (EPMA), in order to determine the phases that are formed during the experiments. For the EPMA analyses, WDS point analyses or mappings were performed at either $15 \mathrm{kV}-15 \mathrm{nA}$ or at $5 \mathrm{kV}-15 \mathrm{nA}$. For quantification, standards were used. The EPMA quantification data are within $1 \%$ error.

\section{Results}

\section{$\mathrm{AlF}_{3}$ in $\mathrm{LiF}-\mathrm{Nd}_{2} \mathrm{O}_{3}$ System}

The XRD analysis results of the sample from the LiF$\mathrm{Nd}_{2} \mathrm{O}_{3}-\mathrm{AlF}_{3}$ mixture after fluorination treatment are shown in Fig. 3, illustrating the formation of $\mathrm{NdF}_{3}, \mathrm{LiF}, \mathrm{AlNdO}_{3}$, and $\mathrm{Al}_{2} \mathrm{O}_{3}$ phases. These results thus confirm the formation of $\mathrm{NdF}_{3}$ based on reaction (1).

$\mathrm{Al}, \mathrm{Nd}$, and oxygen distributions shown by EPMA mapping in Fig. 4 provide further evidence for the formation of $\mathrm{Al}-\mathrm{Nd}-\mathrm{O}$ phase, which is identified as $\mathrm{AlNdO}_{3}$ in XRD. Formation of $\mathrm{AlNdO}_{3}$ could inhibit the complete conversion of $\mathrm{Nd}_{2} \mathrm{O}_{3}$ into $\mathrm{NdF}_{3}$. Furthermore, $\mathrm{Nd}$ is distributed in the fluorine areas, which indicates neodymium fluoride formation. The dark phase in the sample is possibly $\mathrm{LiF}$, since the fluorine concentration is very high in this area. Lithium, being a light element, could not be measured by EPMA. The microstructure of the liquid nitrogenquenched sample is shown in Fig. 5. With the help of the EPMA point analysis, different phases present in the samples were identified and are marked. The dark phase with high fluorine concentration is identified as lithium fluoride, and the fibrous phase is $\mathrm{NdF}_{3}$. Fibrous pattern of $\mathrm{NdF}_{3}-\mathrm{LiF}$ eutectic structure is shown in this image. The large light grains correspond to oxides $\left(\mathrm{Al}_{2} \mathrm{O}_{3}, \mathrm{AlNdO}_{3}\right)$. Both aluminum oxide and aluminum neodymium oxide were identified by XRD. The EPMA analysis shows the distribution of neodymium, aluminum, and oxygen in the same areas which can be referred to $\mathrm{AlNdO}_{3}$ phase.

Point analysis of the $\mathrm{LiF}-\mathrm{Nd}_{2} \mathrm{O}_{3}-\mathrm{AlF}_{3}$ sample shows the presence of 77 at $\%$ fluorine and 19 at\% neodymium, forming $\mathrm{NdF}_{3}$ phase, a fluorine-rich phase (LiF), and $\mathrm{AlNdO}_{3}$ (20 at\% aluminum, 17 at $\%$ neodymium, and 62 at\% oxygen). $\mathrm{Al}_{2} \mathrm{O}_{3}$ was not identified in the EPMA. This could be due to the fact that EPMA point analysis is limited to certain areas, whereas the XRD analysis detects the whole sample, wherein the $\mathrm{Al}_{2} \mathrm{O}_{3}$ phase was identified.

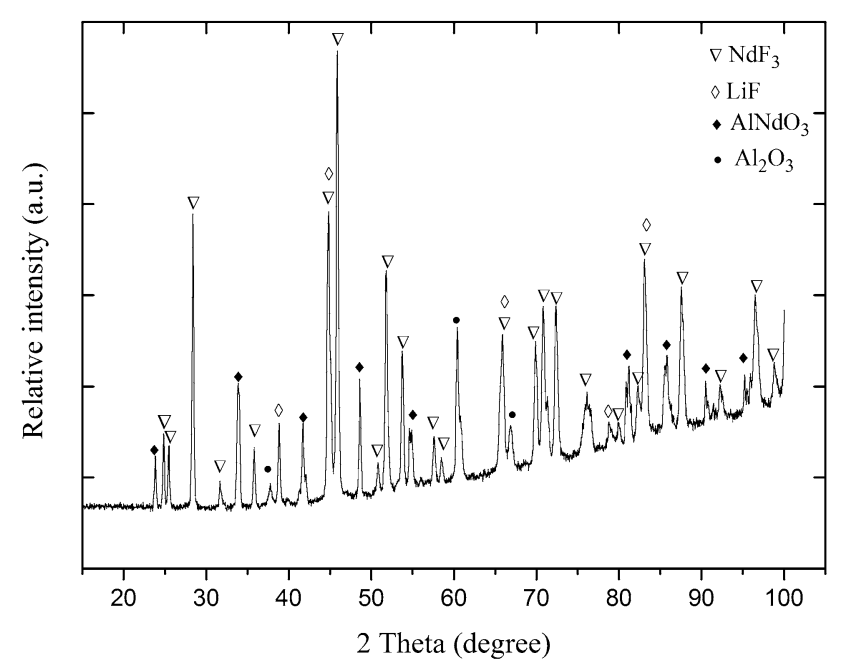

Fig. 3 XRD pattern of $\mathrm{LiF}-\mathrm{Nd}_{2} \mathrm{O}_{3}-\mathrm{AlF}_{3}$ sample after fluorination treatment with identified phases 


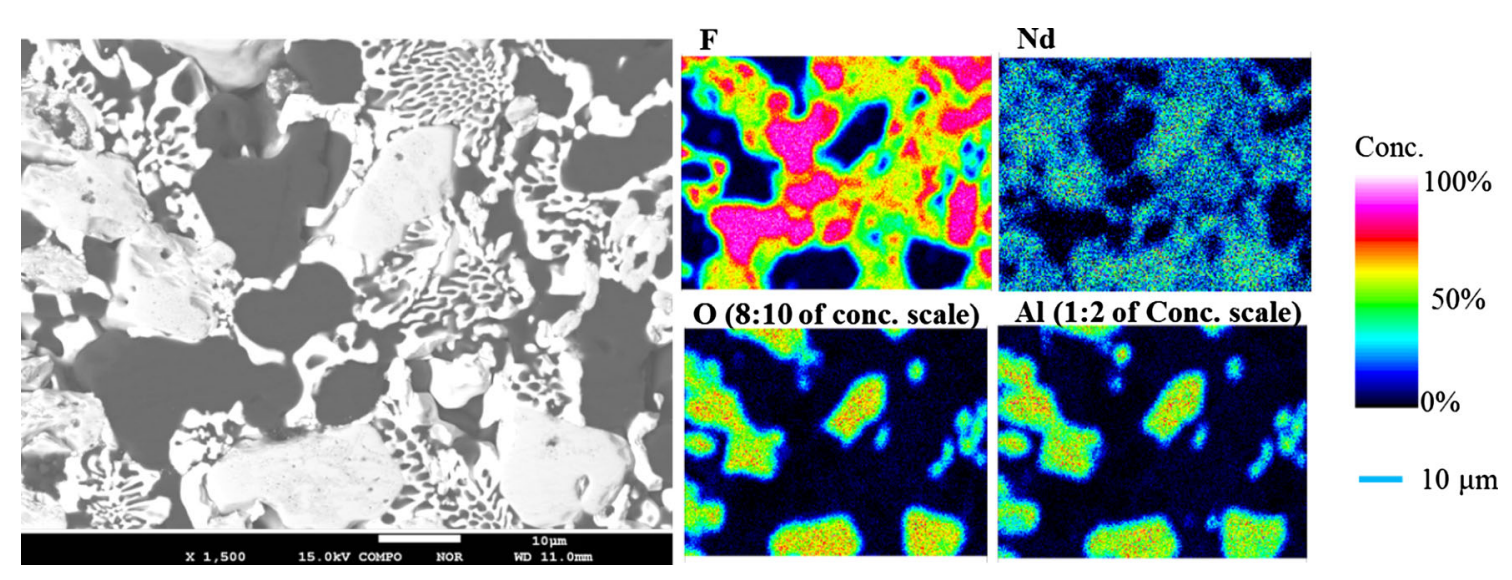

Fig. 4 EPMA mapping images of $\mathrm{LiF}-\mathrm{Nd}_{2} \mathrm{O}_{3}-\mathrm{AlF}_{3}$ sample after fluorination treatment (Color figure online)

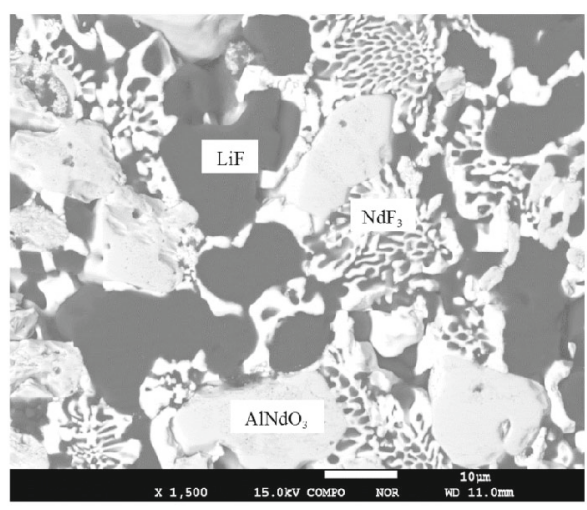

\begin{tabular}{|l|c|c|c|}
\hline Element & $\mathrm{NdF}_{3}$ & $\mathrm{LiF}$ & $\mathrm{AlNdO}_{3}$ \\
\hline $\mathrm{F}$ & 77 & 99.5 & - \\
\hline $\mathrm{Nd}$ & 19 & - & 17 \\
\hline $\mathrm{O}$ & - & - & 62 \\
\hline $\mathrm{Al}$ & - & - & 20 \\
\hline
\end{tabular}

Fig. 5 BSE image and EPMA quantification result of the LiF$\mathrm{Nd}_{2} \mathrm{O}_{3}-\mathrm{AlF}_{3}$ sample in at\% after fluorination treatment, showing the presence of $\mathrm{NdF}_{3}$ and $\mathrm{AlNdO}_{3}$

\section{$\mathrm{ZnF}_{2}$ in $\mathrm{LiF}-\mathrm{Nd}_{2} \mathrm{O}_{3}$ System}

The XRD analysis result for $\mathrm{LiF}-\mathrm{Nd}_{2} \mathrm{O}_{3}-\mathrm{ZnF}_{2}$ after fluorination is shown in Fig. 6. The identified phases are $\mathrm{NdF}_{3}$, $\mathrm{LiF}$, and $\mathrm{ZnO}$. This confirms the complete conversion of $\mathrm{Nd}_{2} \mathrm{O}_{3}$ into $\mathrm{NdF}_{3}$ based on reaction (2).

Very strong peaks of neodymium fluoride indicate that neodymium oxide is converted into neodymium fluoride after reaction with $\mathrm{ZnF}_{2}$. Oxygen is detected only in the zinc oxide phase, and there were no peaks corresponding to the remaining neodymium oxide in the sample. Hence neodymium oxide is considered to have been completely converted into neodymium fluoride. It should be noted that no oxyfluoride phase was detected by XRD analysis.

The EPMA mapping images in Fig. 7 also clearly show the formation of $\mathrm{NdF}_{3}$ and $\mathrm{ZnO}$ as separate phases. Mapping (a) was analyzed at $15 \mathrm{kV}$ voltage; however, for more

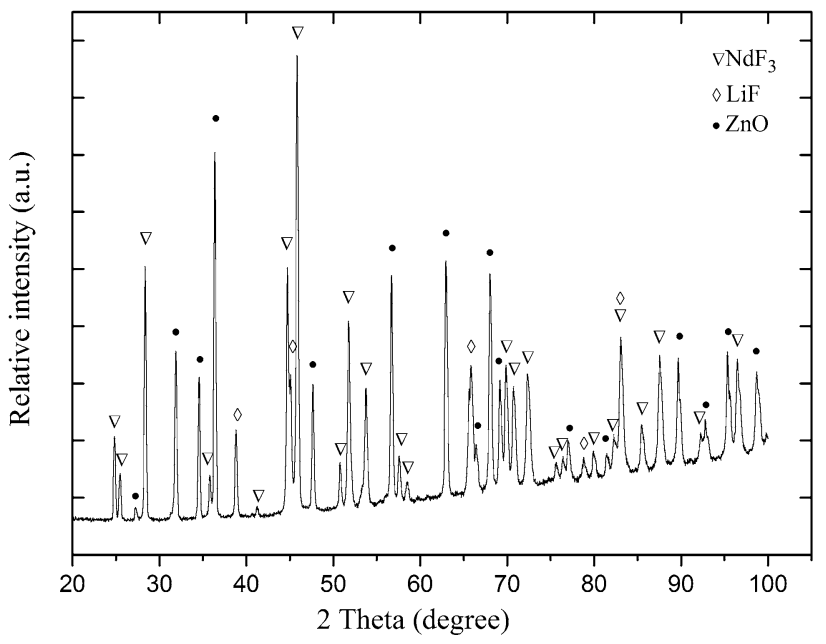

Fig. 6 XRD pattern of $\mathrm{LiF}-\mathrm{Nd}_{2} \mathrm{O}_{3}-\mathrm{ZnF}_{2}$ sample after fluorination treatment with identified phases

details and a clear distinction between the two phases, mapping (b) was performed at a lower voltage level of $5 \mathrm{kV}$. The $\mathrm{LiF}-\mathrm{NdF}_{3}$ eutectic microstructure, lamellar $\mathrm{NdF}_{3}$ phase in the LiF phase, is visibly shown in this image. In this figure, it is clearly shown that neodymium is distributed in the lamellar phase and fluorine is found in both microstructural constituents. The level of fluorine in the black phase is twice that of the lamellar phase which is a reflection of the presence of $\mathrm{LiF}$ as the basic salt constituent (solvent).

The EPMA point analysis of the $\mathrm{LiF}-\mathrm{Nd}_{2} \mathrm{O}_{3}-\mathrm{ZnF}_{2}$ sample after fluorination treatment with the elemental quantification is shown in Fig. 8. The results show the presence of dark gray $\mathrm{ZnO}$ grains in a lamellar $\mathrm{LiF}-\mathrm{NdF}_{3}$ eutectic matrix. The quantifications show that no oxyfluoride phase is formed and that all neodymium oxide has been converted into neodymium fluoride. The lamellar light gray phase having fluorine and neodymium in a 3:1 atomic ratio proves the formation of neodymium fluoride. 

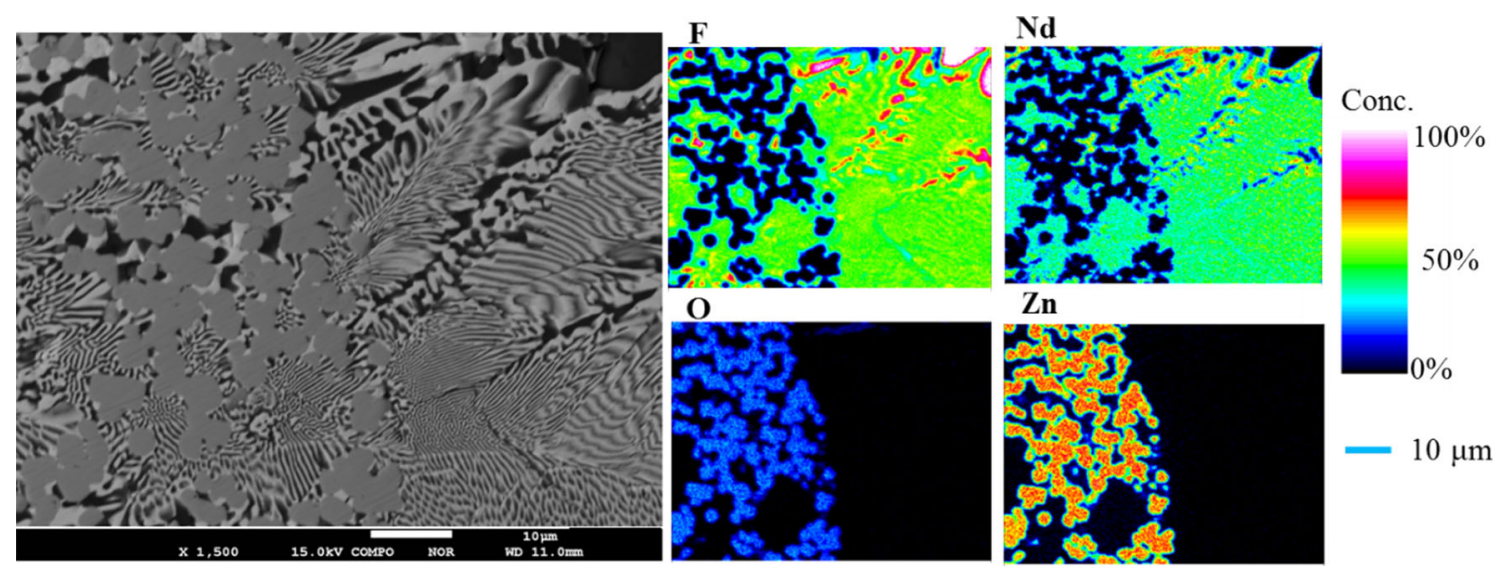

(a)
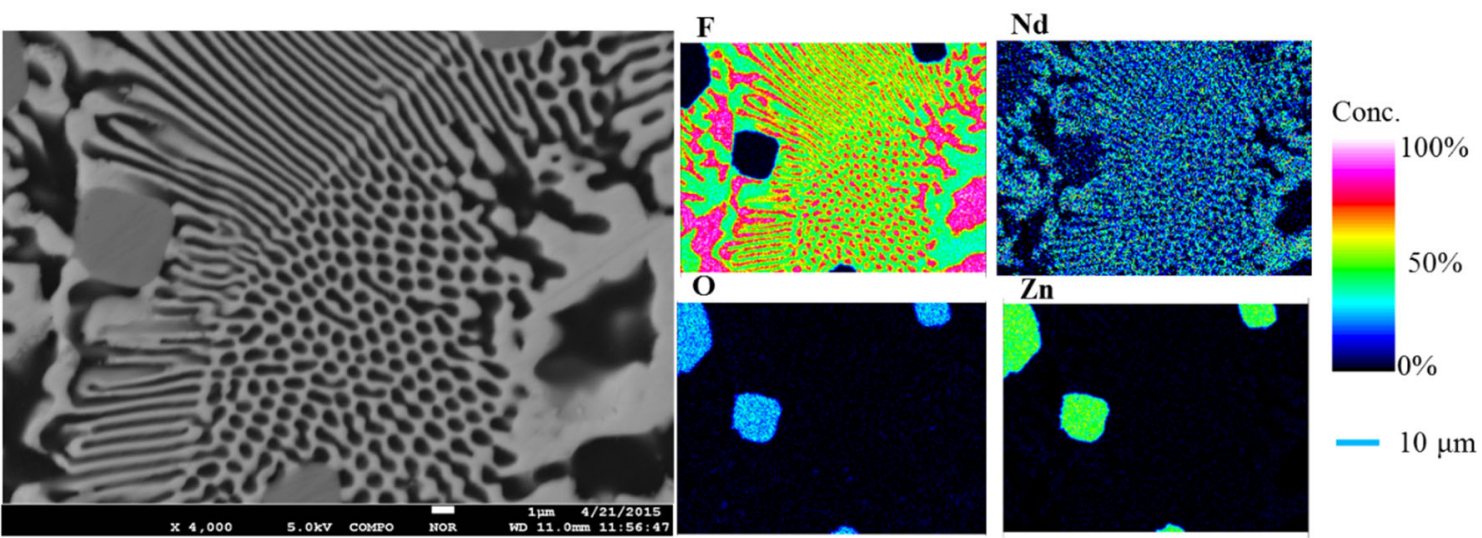

(b)

Fig. 7 EPMA mapping images of $\mathrm{LiF}-\mathrm{Nd}_{2} \mathrm{O}_{3}-\mathrm{ZnF}_{2}$ sample after fluorination treatment: a analyzed at $15 \mathrm{kV}$ and $\mathbf{b}$ at $5 \mathrm{kV}$ (Color figure online)

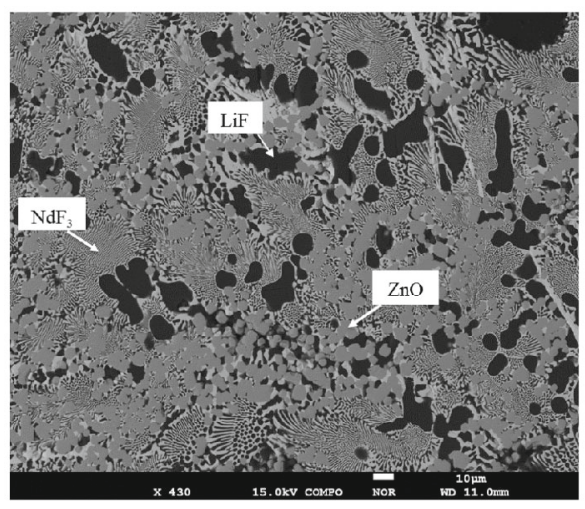

\begin{tabular}{|l|l|l|l|}
\hline Element & $\mathrm{NdF}_{3}$ & $\mathrm{ZnO}$ & $\mathrm{NdF}_{\mathrm{x}}$ \\
\hline $\mathrm{F}$ & 74 & - & 89 \\
\hline $\mathrm{O}$ & - & 47 & - \\
\hline $\mathrm{Nd}$ & 25 & - & 10 \\
\hline $\mathrm{Zn}$ & - & 52 & - \\
\hline
\end{tabular}

Fig. 8 BSE image and EPMA quantification result of $\mathrm{LiF}-\mathrm{Nd}_{2} \mathrm{O}_{3}-$ $\mathrm{ZnF}_{2}$ sample in at $\%$ after fluorination treatment showing the presence of $\mathrm{NdF}_{3}$ and $\mathrm{ZnO}$
$\mathrm{NdF}_{3}-\mathrm{LiF}$ eutectic structure is clearly shown in the EBS image. Measurement of $\mathrm{NdF}_{x}$ phase indicates (referring to the table under Fig. 8) that the fluorine concentration is relatively high (nine times the $\mathrm{Nd}$ concentration). High concentration value for fluorine can be due to the fact that this data is obtained using area analysis with the radius of $7 \mu \mathrm{m}$ wihich contains both $\mathrm{NdF}_{3}$ and LiF. Li cannot be detected by EPMA. The small gray grains correspond to the presence of the $\mathrm{ZnO}$ phase ( $\mathrm{Zn} 52$ at\% and $\mathrm{O} 47$ at $\%$ ).

\section{$\mathrm{FeF}_{3}$ in $\mathrm{LiF}-\mathrm{Nd}_{2} \mathrm{O}_{3}$ System}

The result of the XRD analysis of the $\mathrm{LiF}-\mathrm{Nd}_{2} \mathrm{O}_{3}-\mathrm{FeF}_{3}$ sample is shown in Fig. 9. The strong peaks of neodymium fluoride prove the oxide-to-fluoride conversion. $\mathrm{FeO}$ is formed during the reaction between iron fluoride and neodymium oxide. As mentioned earlier, in the Ar ambient and low oxygen pressure atmosphere, hematite $\left(\mathrm{Fe}_{2} \mathrm{O}_{3}\right)$ will not be formed or, depending upon the prevailing oxygen pressure, the formed $\mathrm{Fe}_{2} \mathrm{O}_{3}$ would be decomposed 
to $\mathrm{Fe}_{3} \mathrm{O}_{4}$ and $\mathrm{FeO}$. At temperatures higher than the eutectoid temperature (ca. $560{ }^{\circ} \mathrm{C}$ ) for $\mathrm{FeO}$ in equilibrium with metallic iron and $\mathrm{Fe}_{3} \mathrm{O}_{4}$, the stable oxide is wüstite $(\mathrm{FeO})$. Furthermore, three peaks were detected in the XRD pattern corresponding to the presence of $\mathrm{NdOF}$ phase.

In the EPMA mapping, the distribution of iron and oxygen is clearly shown. Based on the mapping images, neodymium is highly concentrated around the $\mathrm{FeO}$ grain boundaries. Oxygen and fluorine are also present in these areas at very low concentrations (Fig. 10). Hence neodymium oxyfluoride is found in these areas, which was detected by XRD. Based on the mapping images, the lamellar phase is $\mathrm{NdF}_{3}$ in the $\mathrm{LiF}$, indicating the $\mathrm{LiF}-\mathrm{NdF}_{3}$ eutectic microstructure.

The BSE images and EPMA quantification results are shown in Fig. 11. In this figure, the presence of $\mathrm{FeO}$ (45 at\% $\mathrm{Fe}$ and 54 at\% O) grains is seen. This phase can be a mixture of $\mathrm{FeO}$ and $\mathrm{Fe}_{2} \mathrm{O}_{3}$, since concentration can also

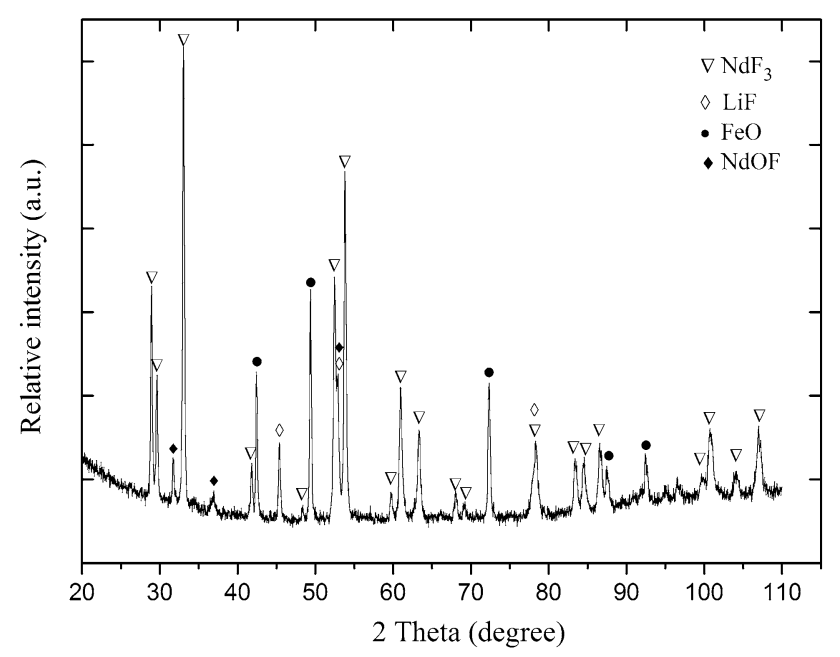

Fig. 9 XRD pattern of $\mathrm{LiF}-\mathrm{Nd}_{2} \mathrm{O}_{3}-\mathrm{FeF}_{3}$ sample after fluorination treatment with identified phases be related to magnetite phase $\left(\mathrm{Fe}_{3} \mathrm{O}_{4}\right)$. From reaction (3), $\mathrm{Fe}_{2} \mathrm{O}_{3}$ formation is expected, but as both XRD and EPMA results show, the oxide of iron formed is wüstite or nonstoichiometric $\mathrm{FeO}_{x}$. However, oxygen measurement by EPMA at $15 \mathrm{kV}$ is not precise.
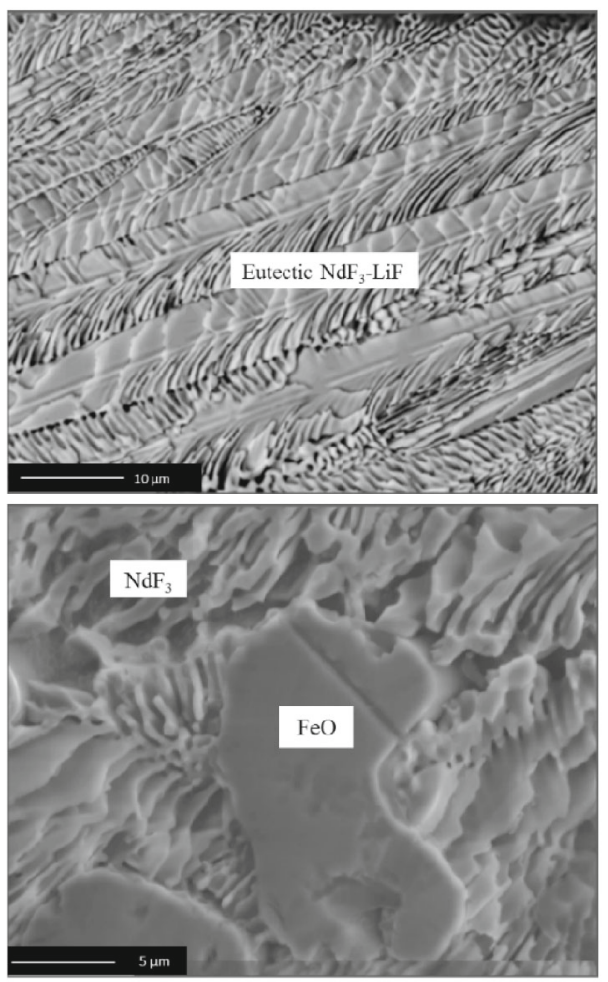

\begin{tabular}{|l|l|l|}
\hline Element & $\mathrm{NdF}_{3}$ & $\mathrm{FeO}$ \\
\hline $\mathrm{F}$ & 72 & - \\
\hline $\mathrm{O}$ & - & 54 \\
\hline $\mathrm{Nd}$ & 26 & - \\
\hline $\mathrm{Fe}$ & - & 45 \\
\hline
\end{tabular}

Fig. 11 BSE image and EPMA quantification result of LiF-Nd2O3$\mathrm{FeF} 3$ sample in at\% after fluorination treatment showing the presence of $\mathrm{NdF}_{3}$ and $\mathrm{FeO}$
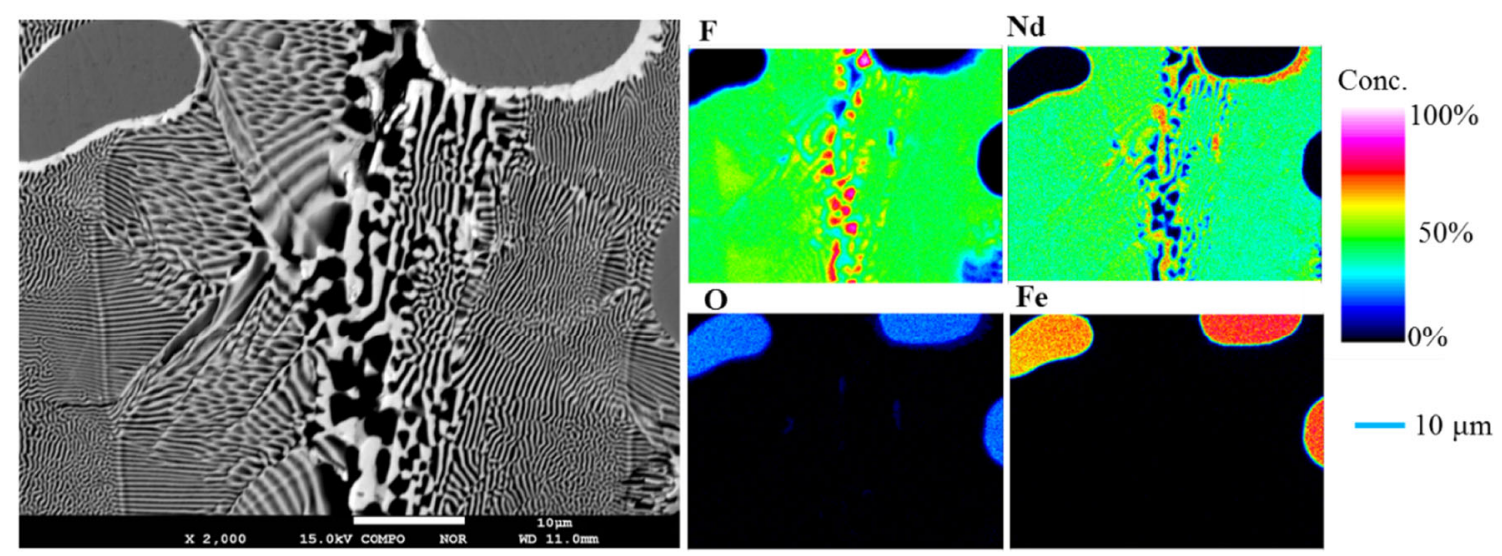

Fig. 10 EPMA mapping of $\mathrm{LiF}-\mathrm{Nd}_{2} \mathrm{O}_{3}-\mathrm{FeF}_{3}$ sample after fluorination treatment showing the presence of $\mathrm{NdF}_{3}$ and $\mathrm{FeO}(\mathrm{Color}$ figure online) 
In Fig. 11, the presence of needle-shaped grains of neodymium fluoride is seen. No neodymium oxyfluoride phase was detected by EPMA in the selected area of the sample. However, in XRD results of the same sample (Fig. 9), small peaks corresponding to $\mathrm{NdOF}$ phase could be detected. Considering the fact that XRD analysis is valid for the whole sample while EPMA analysis is limited to certain areas, it is assumed that NdOF is formed as a result of the chemical reaction. The EPMA quantitative analysis shows the presence of 26 at $\% \mathrm{Nd}$ and 72 at $\% \mathrm{~F}$.

\section{$\mathrm{Na}_{3} \mathrm{AlF}_{6}$ in $\mathrm{LiF}-\mathrm{Nd}_{2} \mathrm{O}_{3}$ System}

Figure 12 shows the XRD results of the $\mathrm{LiF}-\mathrm{Nd}_{2} \mathrm{O}_{3}-\mathrm{Na}_{3}$ $\mathrm{AlF}_{6}$ system after fluorination. It can be seen that unlike the $\mathrm{NdF}_{3}$ formation in other systems, in this system $\mathrm{Na}_{1.5}$ $\mathrm{Nd}_{1.5} \mathrm{~F}_{6}$ compound is formed. It seems that neodymium from neodymium oxide reacts with cryolite and gets substituted in place of aluminum in the cryolite. Therefore, peaks corresponding to $\mathrm{AlNdO}_{3}$ and also three peaks - an unexpected result_related to aluminum metal were observed. This observation is inexplicable at this stage and thus is not discussed further in this study.

The EPMA analysis results depicted in Fig. 13 show the distribution of fluorine and neodymium in the same areas, indicating the presence of neodymium fluoride. It can be seen that large grains in the sample (indicated in the picture) consist of aluminum, oxygen, and neodymium, which show the presence of AlNdO.

The BSE image and the EPMA quantification results of $\mathrm{LiF}-\mathrm{Nd}_{2} \mathrm{O}_{3}-\mathrm{Na}_{3} \mathrm{AlF}_{6}$ sample shown in Figure 14 indicate the formation of $\mathrm{Nd}_{1.5} \mathrm{Na}_{1.5} \mathrm{~F}_{6}$ lamellar structure containing 18 at $\% \mathrm{Nd}, 11$ at $\% \mathrm{Na}$, and 70 at $\% \mathrm{~F}$ and the $\mathrm{AlNdO}$ phase with 21 at $\% \mathrm{Nd}, 22$ at\% $\mathrm{Al}$, and 54 at\% $\mathrm{O}$. These results

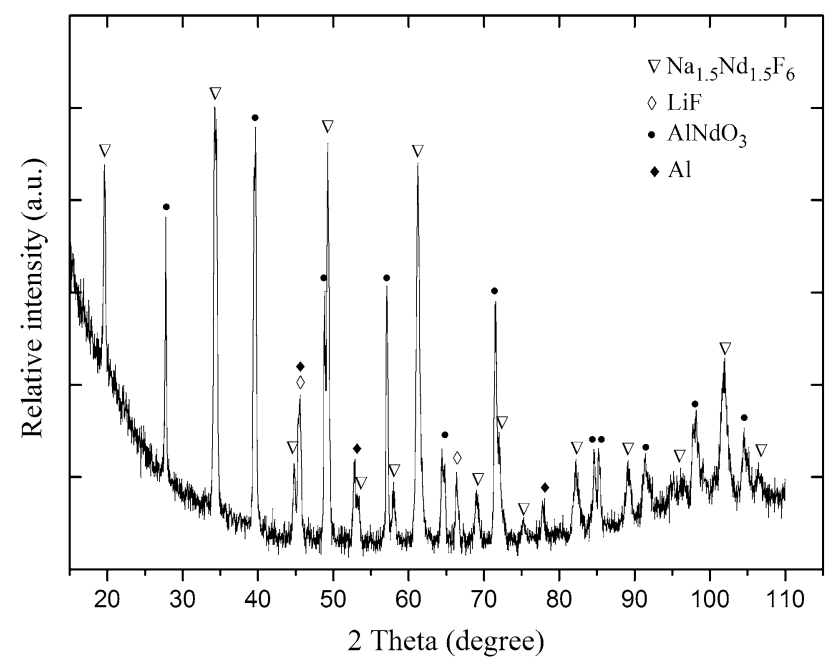

Fig. $12 \mathrm{XRD}$ pattern of $\mathrm{LiF}-\mathrm{Nd}_{2} \mathrm{O}_{3}-\mathrm{Na}_{3} \mathrm{AlF}_{6}$ sample after fluorination treatment with identified phases are in line with the results of XRD obtained for the same sample.

\section{Discussion}

Among the four fluorides used as fluorinating agents, complete conversion of rare earth oxide into rare earth fluoride is observed only in the case when $\mathrm{ZnO}$ is used. According to the Gibbs formation energy of reactions (1)(4) at $950{ }^{\circ} \mathrm{C}$, formation of $\mathrm{NdF}_{3}$ as a result of reaction of $\mathrm{Nd}_{2} \mathrm{O}_{3}$ with $\mathrm{ZnO}$ is the most favorable reaction since it has the lowest Gibbs energy under standard conditions.

The reaction related to cryolite has the highest Gibbs energy and hence has the lowest tendency for the formation of $\mathrm{NdF}_{3}$. Instead of neodymium fluoride, $\mathrm{Na}_{1.5} \mathrm{Nd}_{1.5} \mathrm{~F}_{6}$ is formed. Some of the oxide phase is also found in the form of $\mathrm{AlNdO}_{3}$. In the next step of the process, which is electrochemical reduction of the rare earth on cathode, neodymium should be extracted from $\mathrm{Na}_{1.5} \mathrm{Nd}_{1.5} \mathrm{~F}_{6}$. $\mathrm{Na}$ was also expected to get co-deposited with $\mathrm{Nd}$ on the cathode.

Results of the $\mathrm{LiF}-\mathrm{Nd}_{2} \mathrm{O}_{3}-\mathrm{AlF}_{3}$ system show that neodymium from neodymium oxide gets substituted for aluminum, resulting in the formation of neodymium fluoride. But the complete conversion was obviously not attained since some neodymium was detected in the oxide phase in $\mathrm{AlNdO}_{3}$. Adding an excess amount of $\mathrm{AlF}_{3}$ to the system can result in the complete conversion of neodymium oxide, which needs to be proved in the future research.

In the case of $\mathrm{FeF}_{3}$, three small peaks in XRD, corresponding to the neodymium oxyfluoride phase, were identified; in the EPMA mapping of this system, neodymium was found to be highly concentrated around the $\mathrm{FeO}$ grain boundaries, whereas oxygen and fluorine are were found at very low concentrations. This led to the conclusion that a small fraction of oxyfluoride is present in this system; however, most of the neodymium oxide got converted into neodymium fluoride.

In-situ formation of $\mathrm{REF}_{3}$ is very important since the solubility of REOs is very low in molten fluorides [20]. Further, an additional advantage is that the formation of rare earth oxyfluoride is likely to be inhibited. Stefanidaki et al. [20] have studied the oxide solubility and Raman spectra of $\mathrm{Nd}_{2} \mathrm{O}_{3}$ in the molten alkali fluorides. The authors have reported that the octahedral $\left[\mathrm{NdF}_{6}\right]^{3-}$ anion is the dominant complex in the eutectic $\mathrm{NdF}_{3}-\mathrm{LiF}$ melt system. With the addition of $\mathrm{Nd}_{2} \mathrm{O}_{3}$, complexes that are likely to be formed in the melt would be $\left[\mathrm{NdOF}_{4}\right]^{3-}$ and $\left[\mathrm{NdOF}_{5}\right]^{4-}$. These authors have suggested reaction (14) for the solubility of neodymium oxide in the $\mathrm{LiF}-\mathrm{NdF}_{3}$ eutectic melt. Taxil et al. [15] showed that the oxyfluoride is an insoluble compound. The controversy of the present results demands for the further investigation on the impact of the 

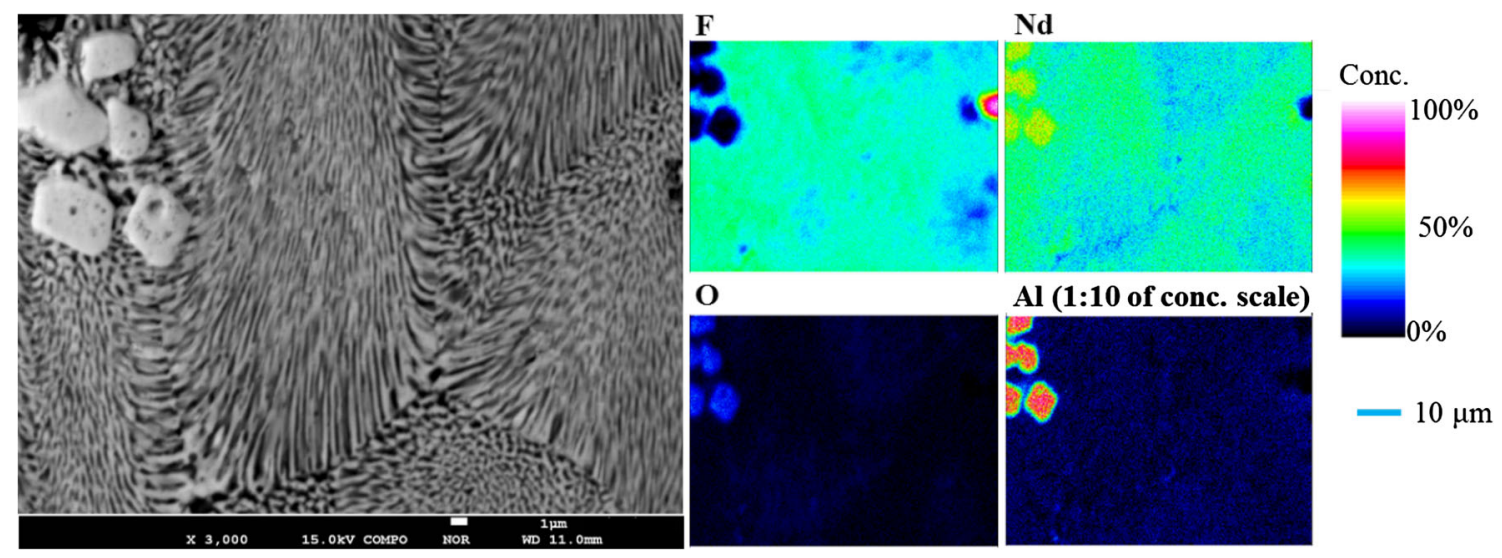

Fig. 13 EPMA mapping of $\mathrm{LiF}-\mathrm{Nd}_{2} \mathrm{O}_{3}-\mathrm{Na}_{3} \mathrm{AlF}_{6}$ sample after fluorination treatment showing the presence of $\mathrm{NdF}_{3}(\mathrm{Color}$ figure online)

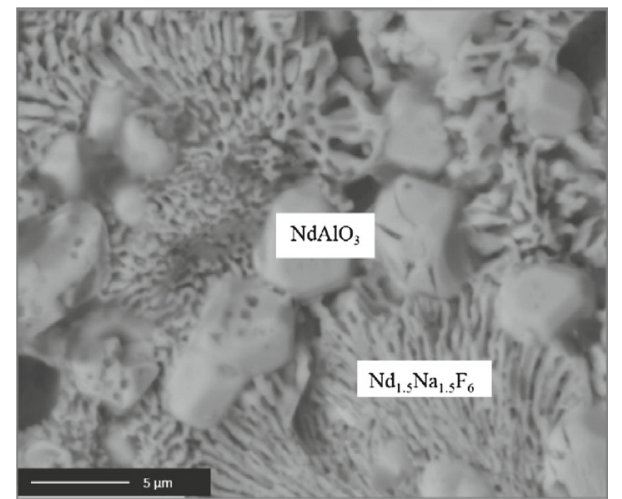

\begin{tabular}{|c|c|c|}
\hline Element & $\mathrm{Nd}_{\mathrm{x}} \mathrm{Na}_{\mathrm{y}} \mathrm{F}_{\mathrm{z}}$ & $\mathrm{NdAlO}$ \\
\hline $\mathrm{F}$ & 70 & - \\
\hline $\mathrm{O}$ & - & 54 \\
\hline $\mathrm{Al}$ & - & 22 \\
\hline $\mathrm{Nd}$ & 18 & 21 \\
\hline $\mathrm{Na}$ & 11 & - \\
\hline
\end{tabular}

Fig. 14 BSE images and EPMA quantification result of $\mathrm{LiF}-\mathrm{Nd}_{2} \mathrm{O}_{3}-$ $\mathrm{Na}_{3} \mathrm{AlF}_{6}$ sample in at\% after fluorination treatment showing the presence of $\mathrm{Nd}_{1.5} \mathrm{Na}_{1.5} \mathrm{~F}_{6}$ and $\mathrm{NdAlO}$

oxyfluoride; hence further research is needed on the solubility of the formed oxyfluoride and the possible reduction mechanism.

The cyclic voltammetry $(\mathrm{CV})$ results for the $\mathrm{LiF}-\mathrm{Nd}_{2} \mathrm{O}_{3}$ system showed that the neodymium oxyfluoride is not reduced to neodymium metal; hence this system is unsuitable for neodymium production [12]. In the voltammetric characterization of the $\mathrm{LiF}-\mathrm{NdF}_{3}-\mathrm{Nd}_{2} \mathrm{O}_{3}$ system, the same voltammogram is found for the $\mathrm{LiF}-\mathrm{NdF}_{3}$ system [12]. It is concluded that neodymium is reduced on the cathode by electroreduction of neodymium fluorides (present in the form of $\left[\mathrm{NdF}_{6}\right]^{3-}$ ), while oxygen is generated on the glassy carbon anode by the oxidation of neodymium oxyfluorides (present in the form of $\left[\mathrm{NdOF}_{5}\right]^{4-}$ ), producing $\mathrm{CO}$ and $\mathrm{CO}_{2}$ gases. According to Taxil et al.
[15], RE fluorides in the presence of the metal oxides will form rare earth oxyfluoride which is an insoluble product and thus it cannot participate in the electrochemical reactions. Dysinger and Murphy [21] have explained that the formation of neodymium oxyfluoride could be one factor to decrease the current efficiency. Hence the formation of rare earth oxyfluoride as an insoluble product is a significant drawback in the extraction of rare earth in molten salts, since they do not participate in the cathodic reactions and thereby lower the current efficiency. However, conversion of neodymium oxide into neodymium fluoride preempts the formation of neodymium oxyfluoride, since neodymium fluoride formation is thermodynamically favorable and it is formed directly as a result of the chemical reaction between neodymium oxide and fluorinating agents.

\section{Microstructure}

The maximum conductivity of the electrolyte is usually observed at the eutectic compositions of the fluoride salts. In all the experiments in this work, the stoichiometry of neodymium oxide and the fluorinating agent was calculated based on theoretical values of reactions $1-4$, assuming that if complete conversion of neodymium oxide occurs, then LiF$\mathrm{NdF}_{3}$ forms the eutectic composition. The eutectic composition of $\mathrm{LiF}-\mathrm{NdF}_{3}$ system was experimentally determined to be 0.23 mol fraction of $\mathrm{NdF}_{3}$ [19] and was calculated to be about $0.25 \mathrm{~mol}$ fraction of $\mathrm{NdF}_{3}$ by van der Meer et al. [22]. The $\mathrm{LiF}-\mathrm{NdF}_{3}$ phase diagram determined by the same researchers using the experimental data is shown in Fig. 15.

In the case of many systems, the microstructure is dependent on the growth conditions; thus the cooling rate and conditions. Hence it does not resemble the molten state of the salt. However, the volume fraction ratio of the two eutectic phases can lead to the formation of lamellar, fibrous, or mixed microstructures. In general, when both phases have comparable volume fractions, a lamellar structure is formed [23]. 


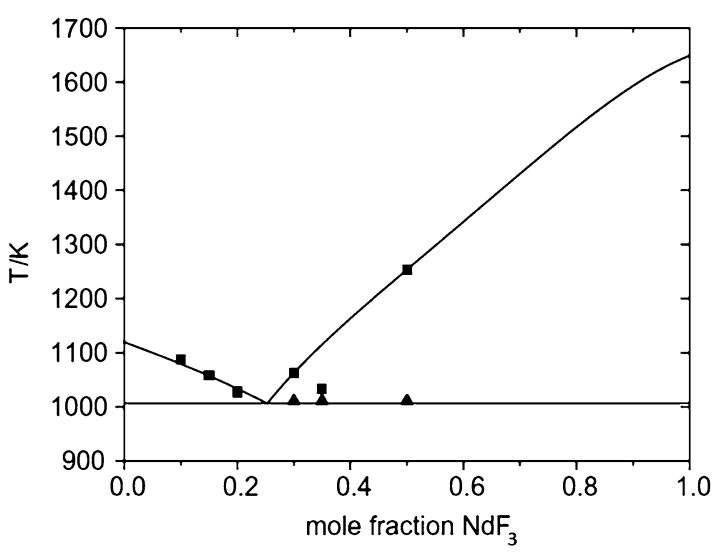

Fig. 15 The optimized $\mathrm{LiF}-\mathrm{NdF}_{3}$ phase diagram: (filled square) experimental data liquidus; (filled triangle) experimental data solidus $[19,22]$

Due to the fast cooling using liquid nitrogen in all four systems, a fine eutectic structure with small alternations $\mathrm{LiF}$ and $\mathrm{NdF}_{3}$ lamellar is formed (Figs. 5, 8, 11, 14). In $\mathrm{LiF}-\mathrm{Nd}_{2} \mathrm{O}_{3}-\mathrm{ZnF}_{2}$ and $\mathrm{LiF}-\mathrm{Nd}_{2} \mathrm{O}_{3}-\mathrm{FeF}_{3}$ systems, XRD analysis shows that most of the neodymium oxide is converted into neodymium fluoride. Hence the composition of the $\mathrm{LiF}-\mathrm{NdF}_{3}$ mixture would be close to the eutectic. The lamellar microstructure of the $\mathrm{NdF}_{3}$ light phase in the $\mathrm{LiF}$ dark phase shown in Figs. 7, 8, 10, and 11 infers that the volume fraction of $\mathrm{LiF}$ and $\mathrm{NdF}_{3}$ is close to the eutectic composition. Also in the case of the system $\mathrm{LiF}-\mathrm{Nd}_{2} \mathrm{O}_{3}-$ $\mathrm{Nd}_{2} \mathrm{Al}_{3} \mathrm{~F}_{6}$, the lamellar microstructure is observed; however, in this system $\mathrm{Nd}_{1.5} \mathrm{Na}_{1.5} \mathrm{~F}_{6}$ is formed instead of $\mathrm{NdF}_{3}$. There are insufficient data in the literature for this system, but the microstructure observations show that LiF$\mathrm{Nd}_{1.5} \mathrm{Na}_{1.5} \mathrm{~F}_{6}$ behaves very similar to the eutectic composition of $\mathrm{LiF}-\mathrm{NdF}_{3}$ system. In the $\mathrm{LiF}-\mathrm{Nd}_{2} \mathrm{O}_{3}-\mathrm{AlF}_{3}$ system, the presence of $\mathrm{NdAlO}_{3}$ shows that not all the neodymium oxide is converted into neodymium fluoride. Hence the volume fraction of $\mathrm{NdF}_{3}$ is expected to be lower than 0.25 . With decrease in the volume fraction of one

$$
\begin{aligned}
& \mathrm{Nd}_{2} \mathrm{O}_{3}+\mathrm{NdF}_{3}+3(x-1) \mathrm{LiF} \rightleftarrows 3 \mathrm{NdOF}_{x}^{(x-1)-} \\
& \quad+3(x-1) \mathrm{Li}^{+} \quad x=4,5
\end{aligned}
$$

phase below 0.29 , the microstructure forms the fibrous pattern. Fibrous microstructure in Fig. 5 indicates that the microstructure corresponds to a non-eutectic phase. With the increasing growth velocity, the dimensions of the two phases are expected to decrease [23, 24].

\section{Alloy Formation}

The neodymium fluoride which is formed will be dissolved in the molten $\mathrm{LiF}$ and will be subjected to electrolysis when the appropriate voltage is applied. As shown in Fig. 1, the voltage needed for $\mathrm{NdF}_{3}$ electrolysis would be higher than the decomposition voltage of the other oxides which are present in the system. Hence the dissolved $\mathrm{Al}_{2} \mathrm{O}_{3}, \mathrm{ZnO}$, and $\mathrm{FeO}$ will also participate in the electro-decomposition process, and the co-deposition of $\mathrm{Al}, \mathrm{Zn}$, and $\mathrm{Fe}$ will occur at the cathode. Therefore, removal of the undissolved oxides so as to minimize their side effect on cathodic deposition of $\mathrm{Nd}$ is a challenging task. A new design of a two-chamber furnace system is one way for removing the undissolved oxides. The density difference between the formed oxide and the fluoride bath could also be used to separate the oxides from the molten salt.

At the carbon anode, there is likely to be a competition between oxygen gas and fluorine gas evolution. In the former case, oxidation reactions between the carbon anode and the oxygen gas lead to the formation of $\mathrm{CO}$ or $\mathrm{CO}_{2}$ gas (reactions 11-12) and in the latter case, reaction between fluorine gas and the carbon anode results in the formation of fluorocarbon compounds (reaction 13), such as $\mathrm{CF}_{4}$ and $\mathrm{C}_{2} \mathrm{~F}_{6}$ [25]. $\mathrm{CO}$ and $\mathrm{CO}_{2}$ evolutions have more negative potentials than fluorocarbon or fluorine gas evolution. According to Stefanidaki et al. [12], fluorocarbon generation on the anode can be inhibited by controlling the cell voltage. However, in order to avoid fluorine gas formation, the use of an alternative anode is proposed which will be explained in a further study as the electro-decomposition part of the same project which will follow.

Regarding the cathodic reactions, formation of $\mathrm{Nd}-\mathrm{Fe}$ alloy is desirable since it can be used as a master alloy for magnet production. In this regard, using $\mathrm{FeF}_{3}$ as the fluorinating agent would be a great advantage.

In general, RE-Al can be applied to improve the magnetic properties of the $\mathrm{RE}$ magnets. $\mathrm{Dy}-\mathrm{Ni}-\mathrm{Al}$ eutectic alloy is used in grain boundary diffusion treatment in neodymium magnets in order to improve coercivity [26]. Alloying pure aluminum with rare earth elements is also an effective means to reduce the defect formation in films which are used to interconnect lines in large-scale integration circuits [27].

In the case when cryolite is used, $\mathrm{Nd}_{2} \mathrm{O}_{3}$ is converted into $\mathrm{Na}_{1.5} \mathrm{Nd}_{1.5} \mathrm{~F}_{6}$ instead of $\mathrm{NdF}_{3}$. In the electrolysis step, $\mathrm{Na}$ reduction with $\mathrm{Nd}$ from $\mathrm{Na}_{1.5} \mathrm{Nd}_{1.5} \mathrm{~F}_{6}$ and $\mathrm{Al}$ reduction from $\mathrm{Al}_{2} \mathrm{O}_{3}$ are expected. Hence $\mathrm{Nd}-\mathrm{Al}-\mathrm{Na}$ alloy is formed at the cathode. In order to avoid Na reduction, $\mathrm{AlF}_{3}$ should be used instead of $\mathrm{Na}_{3} \mathrm{AlF}_{6}$.

$\mathrm{Nd}-\mathrm{Zn}$ alloy can be used for magnesium alloying in the production of novel composites. $\mathrm{Zn}$ is the major alloying element of the magnesium materials, and it has been proven that rare earth elements are the most effective alloying elements used to improve the strength and corrosion behavior of zinc $[28,29]$. 


\section{Conclusion}

The results of XRD and EPMA analyses show that $\mathrm{AlF}_{3}$, $\mathrm{ZnF}_{2}$, and $\mathrm{FeF}_{3}$ can act as strong fluorinating agents for neodymium oxide. In all these systems, neodymium oxide was converted into neodymium fluoride. By the addition of $\mathrm{AlF}_{3}, \mathrm{ZnF}_{2}$, and $\mathrm{FeF}$ to the $\mathrm{LiF}-\mathrm{Nd}_{2} \mathrm{O}_{3}$ system, aluminum oxide, zinc oxide, and iron oxide are formed, respectively. In the case of $\mathrm{Na}_{3} \mathrm{AlF}_{6}, \mathrm{Na}_{1.5} \mathrm{Nd}_{1.5} \mathrm{~F}_{6}$ was formed instead of $\mathrm{NdF}_{3}$. Also as a result of the conversion reaction, instead of $\mathrm{Al}_{2} \mathrm{O}_{3}, \mathrm{AlNdO}_{3}$ is formed. In general, cryolite has the least tendency for the formation of $\mathrm{NdF}_{3}$ compared to other fluorinating agents that are studied in this research.

The reaction related to cryolite has the highest Gibbs energy and hence has the lowest tendency for the formation of $\mathrm{NdF}_{3}$.

The results of this study indicate the feasibility of the conversion of the rare earth oxide into rare earth fluoride using fluorinating agents (Fig. 2). Conversion of neodymium oxide into neodymium fluoride solves the problem of low solubility of the neodymium oxide in molten fluorides, to a large extent. Once neodymium fluoride is formed, it can subsequently be electrolyzed and extracted on the cathode. The electrolysis process will be discussed in a separate paper in the future.

Acknowledgement This research has received funding from the European Community's Seventh Framework Programme ([FP7/20072013]) under Grant Agreement No 607411 (MC-ITN EREAN: European Rare Earth Magnet Recycling Network, Project website: www.erean.eu). This publication reflects only the authors' view, exempting the Community from any liability. The authors would also like to thank Ruud Hendrikx and Richard Huizenga for the XRD analyses.

Open Access This article is distributed under the terms of the Creative Commons Attribution 4.0 International License (http://creative commons.org/licenses/by/4.0/), which permits unrestricted use, distribution, and reproduction in any medium, provided you give appropriate credit to the original author(s) and the source, provide a link to the Creative Commons license, and indicate if changes were made.

\section{References}

1. Chen GZ, Fray DJ, Farthing TW (2000) Direct electrochemical reduction of titanium dioxide to titanium in molten calcium chloride. Nature 407:361-364

2. Hirota $\mathrm{K}$ et al (1999) Electrochemical deoxidation of RE-O (RE $=\mathrm{Gd}, \mathrm{Tb}, \mathrm{Dy}, \mathrm{Er})$ solid solutions. J Alloy Compd 282(1-2):101-108

3. Claux B, Serp J, Fouletier J (2011) Electrochemical reduction of cerium oxide into metal. Electrochim Acta 56(7):2771-2780

4. Wang D et al (2006) Electrochemical metallization of solid terbium oxide. Angew Chem Int Ed 45(15):2384-2388

5. Vishnu DSM et al (2013) Factors influencing the direct electrochemical reduction of $\mathrm{UO}_{2}$ pellets to uranium metal in $\mathrm{CaCl}_{2}-48$ mol\% NaCl melt. J Electrochem Soc 160(11):D583-D592
6. Seetharaman S, Grinder O (2010) US patent application nr. 12/991128, ref. no.: 12057

7. Abbasalizadeh A et al (2013) Highlights of the salt extraction process. JOM 65(11):1552-1558

8. Abbasalizadeh A et al (2015) Neodymium extraction using salt extraction process. Miner Process Extr Metall 124(4):191-198

9. Porter B, Brown EA (1961) Determination of oxide solubility in molten fluorides. U.S. Dept. of the Interior, Bureau of Mines, Washington, DC, p 3139

10. Morrice E, Henrie TA (1967) Electrowinning high-purity neodymium, praseodymium, and didymium metals from their oxides. U.S. Dept. of the Interior, Bureau of Mines, Washington, DC

11. Murphy JE, Dysinger DK, Chambers MF (1995) Electrowinning neodymium metal from chloride and oxide-fluoride electrolytes. In: Evans JW (ed) Light metals 1995. The Minerals, Metals \& Materials Society, Warrendale

12. Stefanidaki E, Hasiotis C, Kontoyannis C (2001) Electrodeposition of neodymium from $\mathrm{LiF}-\mathrm{NdF}_{3}-\mathrm{Nd}_{2} \mathrm{O}_{3}$ melts. Electrochim Acta 46(17):2665-2670

13. Kaneko A, Yamamoto Y, Okada C (1993) Electrochemistry of rare earth fluoride molten salts. J Alloy Compd 193:44-46

14. Thudum $\mathrm{R}$ et al (2010) Molten salt electrolysis of neodymium: electrolyte selection and deposition mechanism. Miner Process Extr Metall 119(2):88-92

15. Taxil P et al (2009) Lanthanides extraction processes in molten fluoride media: application to nuclear spent fuel reprocessing. J Fluor Chem 130(1):94-101

16. Zhu H (2014) Rare earth metal production by molten salt electrolysis. In: Kreysa G, Ota K, Savinell R (eds) Encyclopedia of applied electrochemistry. Springer, New York, p 1765-1772

17. Lacassagne $\mathrm{V}$ et al (2002) Structure of high-temperature $\mathrm{NaF}-$ $\mathrm{AlF}_{3}-\mathrm{Al}_{2} \mathrm{O}_{3}$ melts: a multinuclear NMR study. J Phys Chem B 106(8):1862-1868

18. Hu X et al (2010) Density and ionic structure of $\mathrm{NdF}_{3}-\mathrm{LiF}$ melts. J Rare Earths 28(4):587-590

19. Thoma RE et al (1970) Equilibrium relations and crystal structure of lithium fluorolanthanate phases. Inorg Chem 9(5):1096-1101

20. Stefanidaki E et al (2002) Oxide solubility and raman spectra of $\mathrm{NdF} 3-\mathrm{LiF}-\mathrm{KF}-\mathrm{MgF}_{2}-\mathrm{Nd}_{2} \mathrm{O}_{3}$ melts. J Chem Soc Dalton Trans 11:2302-2307

21. Dysinger DK, Murphy JE (1994) Electrowinning of neodymium from a molten oxide-fluoride electrolyte. Report of investigations/1994. p. Medium: X; Size: Pages: (16 p)

22. van der Meer JPM et al (2004) Thermodynamic modelling of LiF$\mathrm{LnF}_{3}$ and $\mathrm{LiF}-\mathrm{AnF}_{3}$ phase diagrams. J Nucl Mater 335(3):345-352

23. Trnovcová V et al (1999) Microstructure and physical properties of superionic eutectic composites of the $\mathrm{LiF}-\mathrm{RF}_{3}(\mathrm{R}=$ rare earth element) system. Solid State Ion 119(1-4):173-180

24. Trnovcová V et al (2000) Microstructure and fast ionic conduction of inorganic fluoride and oxide eutectic composites prepared from the melt. Solid State Ion 136-137:11-17

25. Keller R, Larimer K (1997) Rare earths: science, technology and applications III. The Minerals, Metals and Materials Society, p 175

26. Oono $\mathrm{N}$ et al (2011) Production of thick high-performance sintered neodymium magnets by grain boundary diffusion treatment with dysprosium-nickel-aluminum alloy. J Magn Magn Mater 323(3-4):297-300

27. Sarkar J et al (2009) Thermodynamic modeling and experimental investigation of the magnesium-neodymium-zinc alloys. J Alloy Compd 479(1-2):719-725

28. Zhang C et al (2011) Thermodynamic modeling and experimental investigation of the magnesium-neodymium-zinc alloys. Intermetallics 19(11):1720-1726

29. Polmear IJ (1994) Magnesium alloys and applications. Mater Sci Technol 10(1):1-16 